into two-dimensional movement through the use of a condenser unit changes in the electric capacity of the condenser are converted into changes in voltage which are then amplified and recorded.

The equipment measures $45 \mathrm{~cm} \times 80 \mathrm{~cm} \times$ $80 \mathrm{~cm}$ and it enables the movements to be easily recorded under free conditions, since there is no obstruction in the mouth, such as a clutch, nor any foreign material on occlusal surface, nor other materials disturbing gravity and other movements. It also features very simple preparation and operation.

The recording is made in such a way that threedimensional movement is resolved into twodimensional movement and time dependent changes can also be pursued.

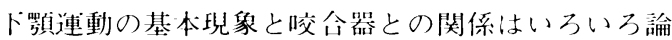
議されているが、卜哿限界運動の再現性の優少をもつ て咬合器の評価をすることも大切であるが、生体の咀 嚼連動、習慣性連動と咬合器との関係を考えてみなけ ればならない。

1912年、Gigmondy が咀嚼運動の研究を発表していら い、多くの研究は莫大な費用と腙間を費して行う研究

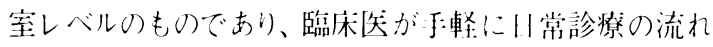
にとり人れられるものではなかった。

このため私達は日常のこれらの現象を身近に調べる

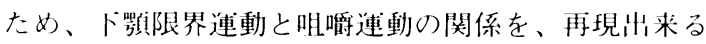
ような装䠝を武作した。装沮の概要はコンデンサーを用 いて、3 次元の連動を 2 次元に分解し、コンデンサー の電気容量の变化を電压の变化として増巾して䛉録計 に沖力する力法を用いた。

装置の大きさは $45 \mathrm{~cm} \times 80 \times 800$ 大きさで、測定用の ため口腔内にクラッチの様なものや咬合面トに買物は なく、重力、その他連動を障害するようなものを入ら ないため、自由な状態での運動が記録出来ることが、 特徵であり、準備、操作が非常に簡単である。

測定は 3 次元連動を 2 次元に分解し、また同時に時 間的経過が追えるようなものである。

\section{6. 咬合音診断の臨床的応用}

\author{
田中良種 (裀阙)
}

\section{Clinical Application of Diagnosis of Occlusal Sound}

Yoshit ane Tanaka (Fukuoka)

The author believes and highly appreciates that the recent tendency to use frequently the terms "Occlusal Analysis" and "Occlusal Diagnosis" reflects the fact that many clinicians have increasingly directed their attention to the close correlation of occlusal problems not only to clinical procedures for prosthodontics but also to conservation, especially for periodontal conditions, as well as to orthodontic and other treatments. A number of theories of occlusion introduced in the past are now being reestablished in combination with the concept that many informations are to be transferred to those articulators based on kinetic occlusal theories. In addition, physiological occlusal theories are to be incorporated into general practice through the development of electronic apparatus. Identification of occlusal sounds has been often used as a supplementary means of diagnosis of occlusion. This is accomplished by the determination of occlusal condition with the mandible moving from the time of occlusal contact to that of disclusion, by catching the vibration with the aid of stethoscope. In dentistry, this method of diagnosis of occlusal sound has not been applied until comparatively recently, when Stewart (1953), Thompson (1954), Schwartz (1959), Silverman (1962) and other workers made attempts to hear the sounds at contact of the teeth or sounds from articulation at the temporomandibular joints directly by ear or indirectly through stethoscope to utilize them as a means of detection of traumatic occlusion, occlusal interference and abnormality in the temporomandibular joints. However, such methods, being dependent upon the subjective 
auditory sense of an individual operator, were very unstable. An additional method using the visual sense has therefore been required. Thus, Ekensten (1952) caught the sound from the temporomandibular joints electrically by microphone to display it continuously on a catch-ray tube oscilloscope for diagnosis of subluxation at the temporomandibular joints. Later, Brenman $(1959 ; 1963 ; 1966 ; 1968)$ caught the tapping sound at the central occlusal position in the same way and measured and compared its duration before and after the occlusal equilibration. In 1972, he developed a diagnostic apparatus for occlusion which was clinically applicable and sold commercially. In Japan, a number of universities and research institutes have also studied this subject and many scientific papers have recently been presented to meetings of dental associations or reprinted in dental journals. The author has for ten years clinically and effectively utilized a flat type stethoscope under the direction of Dr. Sumiya Hobo. He later began development of advice to detect occlusal sound with the aid of an oscilloscope as described above. The result was the successful manufacturing two years age of the Dental Sound Checker applicable to clinical procedure. The method of its use and clinical applications will be described with individual case presentation.

咬合診査並びに、咬合診断という葉が、最近とみ に用いられる様になった背景には、咬令閆題が補緅臨 床のみに関わらず、保存(特にベリ才)、や矯正等に大 いに関与している扎、多くの臨床家が注肌した結果 だと、高く評価できます。過去に於いて奨人された幾 多の咬合理論も、最近に於いては、その連動論的咬合 理論をもとにした咬合器に多くの情報を移送する考え 方に加えて、新たに電子機器の開発により、生理的咬 合理論を一般臨床に組人れていく時代が到来したとも いえます。従来より、咬合彰植の一助として、咬令音 による、“音”の鑑別が盛んに䘕れれていました。即ち、 聴診器を用いて歯牙か咬合に際し、衝突してから離開 寸る迄の下頜運動下の咬合状態を、その振動によりキ ヤッチ寸る方法です。㐘科に抏いて聴診法が応用され る様になったのは、比較的最近の才で、Stewart
(1953)、Thompson (1954)、 Schwartz (1959)、 Silverman（1962）等法、藏の接触音や、颚関節音 を直接耳また法、聴診器を用いて聴取し、外傷性咬令、 咬頭下渉、鹗関節異常などの㛟紧の・手段とした。し かし術者湖人の聴党に頼るこのノ法も、はなはだ不安 定で、視覚に挀える力法が必要となり、電気的に Ekensten (1952) が颚関節の音をマイクロフォンで拐 え、ブラウン管オシロスコーフで連続掫影し、顎関節 の亜脱臼の骖断に䏳いた。ついで Brenman (1959) (1963)(1966)(1968) が问じ方法で忯心咬尔位での tapping 音を拐え、その川等続助閒を計測し、咬合調整の前 後を比較して、1972作臨床に応用できる咬众診断装䈯 在鬥発販している。我が国に於いても、こういうテ 一マに取汲古幾多の大学又研究機関で、研究開発が なされ、学会や蕃学雑誌等での発表が最近、散见され る様になった。私は十件的より、師保母須弥也に指導 され、フラットタイブの聴衫器を用い臨床に存効に利 用していたが、その後能記才シロスコーフによる咬令

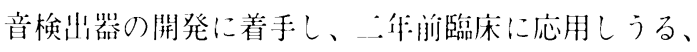
デンタル・サウンド・チェッカーの製作に成功を修め 得た。その使用法及び臨床的忍䏘法等をケースを呈示 し御説明申しはけだた。

\section{質問〉}

サウンド・チェッカーの正常状態および多種異状状 態の模範を示して、一般的手順を解説してトさい。

技工作業上の忠用に対しては、どう拝えですか？

\section{〈解答〉}

忠者のタッヒンング時のオクルーザル・サウンドの種 類は、Impact sound (衝突音)とSliding sound (滑走音) の2 種類で、またそのコンビネーションもあり、それ を彰断の一助とする訳ですが、ベージも少なくて十分 お答えできませんが、近刊の「クインテッセンス」の 中に䛉栽されているのを参考にして下さい。

(技卡、流) サウンド・チェッカーに異常が診断さ れた埸へ、〔腔外にレストレーション又は䛦断模型を トランスファーし、そこでチェック古ることに、技工 上の意義沈あるけれども、殆んどが㟝断、治療または 治療効果、一後診査等に用いるので、クリニカル・サ イドに利用されるものであろう。(H川) 